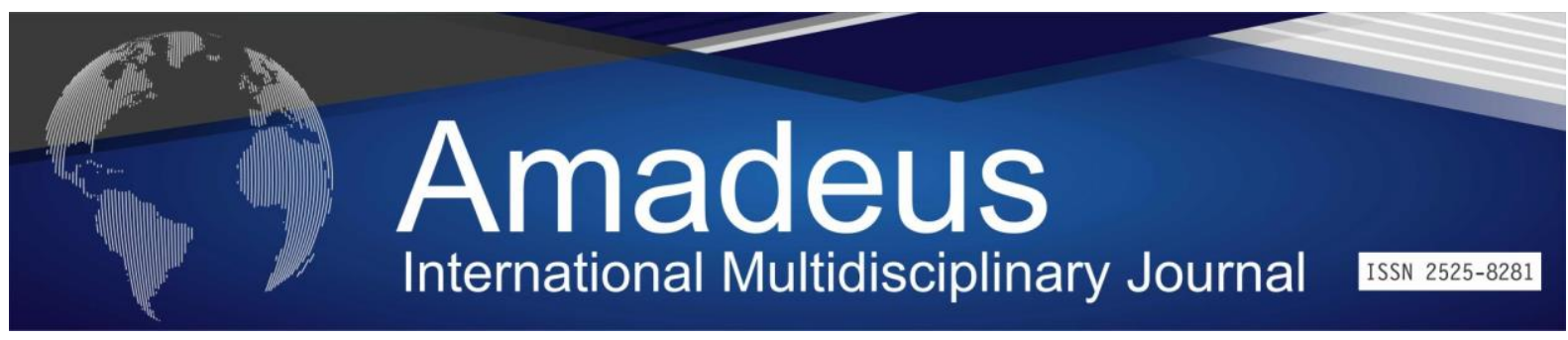

DOI: 10.14295/aimj.v4i8.108

\title{
Radiological Images in Covid-19: An Integrative Review
}

Lucas Tavares Cruz de Albuquerque ${ }^{\text {, }}$ Caroline Pereira Modesto ${ }^{2}$, Ana Beatriz Tavares Cruz de Albuquerque ${ }^{3}$,

Danilo Campos de Moraes Vasconcelos ${ }^{4}$, Raphael Xenofonte Morais Pinheiro $^{5}$

\begin{abstract}
Coronavirus disease 2019 (COVID-19) is an infectious disease caused by the severe acute respiratory syndrome coronavirus (SARS-CoV-2). The objective of this work is to describe the possible radiological manifestations of viral pneumonia caused by the coronavirus, to improve the early detection of this pathology through the use of imaging tests, in addition to the evaluation of the differential diagnoses raised by non-specific respiratory symptoms. When indicated, the protocol is a High Resolution Computed Tomography (HRCT) with low dose protocol, if possible. The use of intravenous contrast medium is reserved for specific situations to be determined by the radiologist. The findings vary according to the time of the disease's evolution, with radiological presentation in 03 (three) distinct phases: initial phase, intermediate phase and late phase. Most commonly, focal or multifocal ground-glass attenuation opacity is evidenced, among others. Imaging exams contribute to the investigation of suspected coronavirus infection and exclusion of other respiratory pathologies that will manifest with different radiological patterns.
\end{abstract}

Keywords: COVID-19. Viral pneumonia. Radiology.

\footnotetext{
${ }^{1}$ Acadêmico de Medicina da Faculdade de Medicina Estácio de Juazeiro do Norte (FMJ), Ceará, Brasil; Contato: lucastavares47@gmail.com

${ }^{2}$ Acadêmica de Medicina da Faculdade de Medicina Estácio de Juazeiro do Norte (FMJ), Ceará, Brasil;

Contato: carolinepmodesto@ hotmail.com

${ }^{3}$ Acadêmica de Medicina da Faculdade de Medicina de Olinda (FMO), Pernambuco, Brasil;

Contato: biatavarees@hotmail.com

${ }^{4}$ Acadêmico de Medicina da Faculdade de Medicina de Olinda (FMO), Pernambuco, Brasil;

Contato: danilocmb@hotmail.com

${ }^{5}$ Radiologista Docente da Faculdade de Medicina Estácio de Juazeiro do Norte (FMJ), Ceará, Brasil;

Contato: radioimip2011@gmail.com
} 


\section{Imagens Radiológicas no Covid-19: Uma Revisão Integrativa}

\begin{abstract}
Resumo: A doença do coronavírus 2019 (COVID-19) é uma doença infecciosa causada pelo coronavírus da síndrome respiratória aguda grave (SARS-CoV-2). O objetivo deste trabalho é descrever as possíveis manifestações radiológicas da pneumonia viral causada pelo coronavírus, para aprimorar a detecção precoce dessa patologia a partir da utilização dos exames de imagem, além da avaliação dos diagnósticos diferenciais suscitados pelos sintomas respiratórios inespecíficos. Quando indicada, o protocolo é de uma Tomografia Computadorizada de Alta Resolução (TCAR) com protocolo de baixa dose, se possível. O uso de meio de contraste endovenoso é reservado para situações específicas a serem determinadas pelo radiologista. Os achados variam conforme o tempo de evolução da doença, com apresentação radiológica em 03 (três) fases distintas: fase inicial, fase intermediária e fase tardia. Evidencia-se mais comumente opacidade de atenuação em vidro fosco focais ou multifocais, entre outros. Os exames de imagem contribuem na investigação da suspeita de infecção pelo coronavírus e exclusão de outras patologias respiratórias que iram se manifestar com diferentes padrões radiológicos.
\end{abstract}

Palavras-chave: COVID-19. Pneumonia Viral. Radiologia.

\section{Introdução}

A doença do coronavírus 2019 (COVID-19) é uma doença infecciosa causada pelo coronavírus da síndrome respiratória aguda grave (SARS-CoV-2) (Perlman, 2020; Hui et al., 2020). Os coronavírus (família Coronaviridae) são vírus RNA de fita simples envelopados, encontrados em humanos, mamíferos e aves, e responsáveis por doenças pulmonares, hepáticas, intestinais e do sistema nervoso central. O SARS-CoV-2 é zoonótico, como em muitas doenças em seres humanos. Por sequência genética, o coronavírus animal mais próximo é o coronavírus do morcego, sendo esta a provável origem do vírus em humanos (Chen, Liu, \& Guo, 2020; Heymann \& Shindo, 2020; Ng \& Hiscox, 2020).

Os primeiros casos de COVID-19 ocorreram na cidade Wuhan, China, em dezembro de 2019, antes da disseminação mundial. Além do COVID-19, outras epidemias causadas pelo coronavírus são: a epidemia da síndrome aguda respiratória grave (SARS) em 20022003 e a epidemia de síndrome respiratória do Oriente Médio (MERS) em 2012 (Perlman, 2020; Hui et al., 2020).

Apesar de ter surgido em animais, o COVID-19 não é considerado uma zoonose direta, visto que sua principal via de transmissão é entre humanos. A doença é transmitida por meio de gotículas das secreções da via aérea superior das pessoas infectadas, ao espirrar 
ou tossir (Heymann \& Shindo, 2020). As gotículas podem ser inaladas, atingir diretamente as mucosas de nariz, olho ou boca, ou se depositar em objetos e superfícies que podem infetar quem nelas toque e leve as mãos às mucosas citadas (Centers For Disease Control And Prevention, 2020a).

$\mathrm{O}$ vírus SARS-CoV-2 afeta, sobretudo, os pulmões. O vírus infeta células a partir da ligação de sua proteína $S$ ao receptor da enzima conversora de angiotensina 2 (ECA2). Esta enzima é comumente encontrada nas células alveolares do tipo II dos pulmões (Zheng et al., 2020). Assim, ao entrar nas células pulmonares, inicia-se o processo de replicação viral e produção de proteínas que inibem o sistema imunológico. Cada célula infectada pode elevar o número de cópias do vírus, infectar novas células e causar os sintomas respiratórios. Conforme novas células alveolares do tipo II são infectadas, a doença pode evoluir para insuficiência respiratória grave e morte (Xu et al., 2020). Além do sistema respiratório, o vírus pode também infectar células do sistema cardiovascular e do trato gastrointestinal que são abundantes em ECA2 (Zheng et al., 2020; H. Zhang et al., 2020).

Idosos e pacientes com comorbidades, como hipertensão arterial sistêmica, diabetes mellitus, doença pulmonar crônica, câncer e imunossupressão, apresentam fatores de risco para doença mais grave e mau prognóstico (Centers For Disease Control And Prevention, 2020c)

O período de incubação entre a exposição do vírus e o início de sintomas é de aproximadamente 05 (cinco) dias, podendo variar de 02 (dois) a 14 (catorze) dias. Vale ressaltar que, no período de incubação, a doença pode ser transmitida para outras pessoas (Lauer et al., 2020). O COVID-19 pode se apresentar como manifestações sistêmicas e/ou respiratórias ou de forma assintomática, atuando como portador (Guan et al., 2020). Nos pacientes sintomáticos, além dos sintomas respiratórias, podem apresentar quadro clínico sugestivo de acometimento gastrointestinal ou cardiovascular, no entanto, são menos comuns (Zheng et al., 2020)

Os sinais e sintomas são inespecíficos, e tem como exemplos (World Health Organization, 2020b):

- Febre $(85-90 \%)$;

- Tosse seca $(65-70 \%)$;

- Fadiga (35-40\%);

- Expectoração (30-35\%);

- Dispneia $(15-20 \%)$; 
- Mialgia/artralgia (10-15\%);

- Cefaleia (10-15\%);

- Faringite (10-15\%);

- Náusea $(<10 \%)$;

- Diarreia $(<5 \%)$.

Até $5 \%$ dos pacientes hospitalizados podem necessitar de cuidado em unidades de terapia intensiva. Entre as possíveis complicações que estes pacientes podem ter, pode-se citar (Guan et al., 2020):

- Síndrome do desconforto respiratório agudo (17-29\%);

- Infecções secundárias;

- Sepse;

- Lesão renal aguda;

- Lesão cardíaca aguda (elevação de troponina, isquemia miocárdica, parada cardíaca).

O diagnóstico definitivo para COVID-19 é através do teste de reação em cadeia de polimerase via transcriptase reversa (RT-PCR). Embora seja altamente específico, apresenta baixa sensibilidade. Assim, um exame inicialmente negativo não exclui a patologia, podendo ser necessário repetir o RT-PCR (Kanne et al., 2020; Mossa-Basha et al., 2020).

Para diminuir a possibilidade de ser infectado pelo vírus do COVID-19, algumas medidas podem ser tomadas: lavar as mãos com água e sabão frequentemente por, no mínimo, 20 (vinte) segundos; caso não seja possível lavar as mãos, utilize álcool a 70\%; evitar tocar boca, olhos e nariz com a mão não lavada; ao tossir ou espirrar, cobrir o nariz com um lenço de papel ou parte interna do cotovelo; limpar e desinfetar diariamente as superfícies frequentemente tocadas e evitar contato próximo com pessoas infectadas ou suspeitas. As máscaras faciais só devem ser usadas em pessoas com sintomas de via aérea ou profissionais de saúde que estejam cuidando de pessoas suspeitas ou infectadas (Centers For Disease Control And Prevention, 2020b). Em casos de surto/epidemia, além das medidas já citadas, é recomendado o distanciamento social (Centers For Disease Control And Prevention, 2020d).

O objetivo deste trabalho é descrever as possíveis manifestações radiológicas da pneumonia viral causada pelo coronavírus, para aprimorar a detecção precoce dessa 
patologia a partir da utilização dos exames de imagem, além da avaliação dos diagnósticos diferenciais suscitados pelos sintomas respiratórios inespecíficos.

\section{Métodos}

É uma revisão integrativa da literatura que abrangeu as seguintes etapas: pergunta norteadora definição; estabelecimento dos objetivos da revisão; demarcação de critérios para inclusão e exclusão de artigos; definição de informações a serem extraídas dos artigos selecionados; resultados análise; discussão e apresentação dos dados obtidos.

Dessa maneira, foram consultadas as seguintes bases de dados: Medical Literature Analysis and Sistema de Recuperação Online (Medline), Scientific Electronic Library Online (Scielo), Latim Literatura Americana e do Caribe em Ciências da Saúde (Lilacs) e (Pubmed) utilizando os descritores: COVID-19, Pneumonia Viral e Radiologia, em inglês, de março a abril de 2020. Os artigos selecionados seguiram os seguintes critérios de inclusão: a) estudos redigidos em inglês em 2020; b) artigos e resenhas originais; c) artigos com texto completo disponível online.

Teses, monografias e trabalhos não publicados foram excluídos do estudo. Adotou-se um formulário para coletar dados dos artigos selecionados, obtendo informações sobre os autores, datas de publicação, objetivos e principais conclusões da pesquisa.

\section{Resultados}

Tabela 1: Autores, objetivos e principais conclusões dos artigos selecionados mais revelantes.

Autores Objetivos Principais Conclusões

Os achados de imagem incluíram

Explicar os achados da

Dai, W. et al., tomografia computadorizada 2020. de pulmão de alguns pacientes com Covid-19. principalmente lesões únicas ou múltiplas, irregulares ou segmentares e marcações reticulares que se seguiram pelas distribuições peribroncovasculares e subpleurais.

Guan, W. et al., 2020. Descrever resultados de análises das características clínicas do Covid-19. Estimar a duração do período

Lauer, S. A. et al., 2020.
Na admissão, a opacidade em vidro fosco foi o achado radiológico mais comum na tomografia computadorizada de tórax.
Este trabalho fornece evidências adicionais para um período médio de incubação do Covid-19 de aproximadamente 5 dias, de incubação do Covid-19 e descrever suas implicações na 


\begin{tabular}{ccc}
\hline & saúde pública. & semelhante aos SARS. \\
\hline $\begin{array}{c}\text { Li, Y. et al., } \\
\text { 2020. }\end{array}$ & $\begin{array}{c}\text { Relatar as características } \\
\text { tomográficas do Covid-19. }\end{array}$ & $\begin{array}{c}\text { Opacidades em vidro fosco e consolidaço } \\
\text { com ou sem aumento vascular, } \\
\text { espessamento septal interlobular e sinal de } \\
\text { broncograma aéreo são características } \\
\text { comuns da TC do Covid-19. }\end{array}$ \\
\hline $\begin{array}{c}\text { Pan, Y. et al., } \\
\text { 2020. }\end{array}$ & $\begin{array}{c}\text { Observar as características de } \\
\text { imagem da nova pneumonia } \\
\text { por coronavírus. }\end{array}$ & $\begin{array}{c}\text { Foi verificada a presença de opacidades em } \\
\text { vidro fosco irregulares/pontiagudas, } \\
\text { consolidações irregulares, faixas fibrosas e } \\
\text { nódulos sólidos irregulares. }\end{array}$ \\
\hline Xu, H. et al., & $\begin{array}{c}\text { Avaliar a alta expressão do } \\
\text { receptor ACE2 de 2019- } \\
\text { nCoV nas células epiteliais da } \\
\text { mucosa oral. }\end{array}$ & $\begin{array}{c}\text { Foi relatado que o ACE2 é o principal } \\
\text { receptor de células hospedeiras de 2019- } \\
\text { nCoV e desempenha um papel crucial na } \\
\text { entrada do vírus na célula, causando a } \\
\text { infecção final. }\end{array}$ \\
\hline
\end{tabular}

Fonte: Dados da pesquisa, 2020.

\section{Discussão}

O Colégio Brasileiro de Radiologia (CBR) e o Centers for Disease Control (CDC), órgão norte-americano, não recomendam radiografia $(\mathrm{Rx})$ ou tomografia computadorizada (TC) de tórax para o diagnóstico de COVID-19. Os testes laboratoriais continuam sendo os métodos específicos para o diagnóstico, mesmo em pacientes com quadro clínico e achados de imagens sugestivos. Os achados da imagem são inespecíficos e, dessa forma, apresentam vários diagnósticos diferenciais (Colégio Brasileiro de Radiologia, 2020).

Os exames de imagem no COVID-19 são indicados em 03 (três) situações (Colégio Brasileiro de Radiologia, 2020):

- Pacientes com quadro clínico e laboratorial de suspeição da doença, principalmente naqueles com quadro clínico mais grave;

- A TC do tórax não deve ser realizada para rastreamento da doença, mas nos pacientes hospitalizados sintomáticos com radiografias normais ou com achados indeterminados;

- Avaliação de complicações e pesquisa de diagnóstico alternativo. 


\section{Radiografia de Tórax}

Em doença precoce ou leve, a radiografia pode não apresentar anormalidades (Figura 1). Na evolução podem surgir opacidades do espaço aéreo (consolidação e, menos comumente, opacidade em vidro fosco) de distribuição, geralmente, bilateral, periférica e inferior. Em relação à TC, os achados da radiografia são tardios (Rodrigues et al., 2020).

Figura 1: Comparação entre radiografia $(\mathrm{Rx})$ e tomografia computadorizada (TC). Observe opacidades em vidro fosco lobo inferior direito (setas vermelhas) na TC não são visíveis na Rx, que foi realizada.

$01 \mathrm{~h}$ antes do estudo da TC.

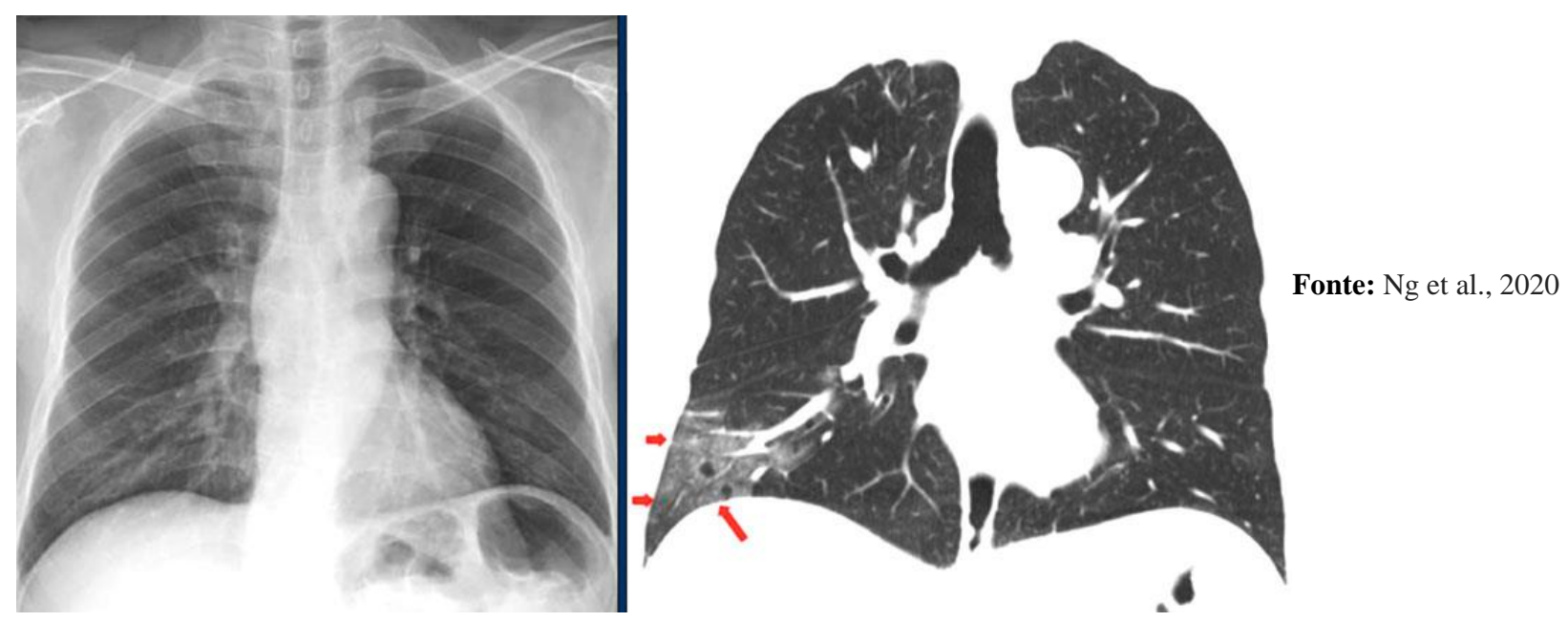

Figura 2: Paciente feminino, 70 anos, apresentando febre e odinofagia com teste positivo para SARS-CoV2. Radiografia: opacidade no lobo inferior direito (seta).

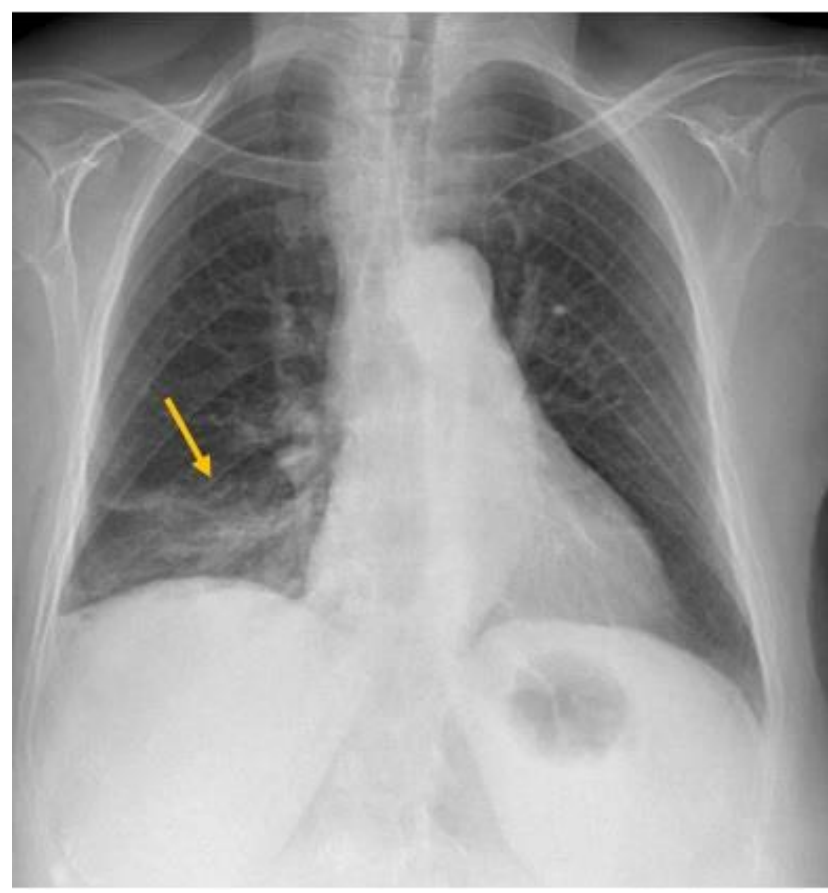

Fonte: Lorente, E. (2020). COVID-19 pneumonia. Disponível em: https://radiopaedia.org/cases/covid-19pneumonia-21?lang=us. 
Na sequência, observe-se outros achados radiológicos e suas descrições.

Figura 3: Paciente masculino, 70 anos, positivo por COVID-19, febre e proteína C reativa elevada. Radiografia: opacidades perihilares e apicais, principalmente periféricas, bilateralmente.

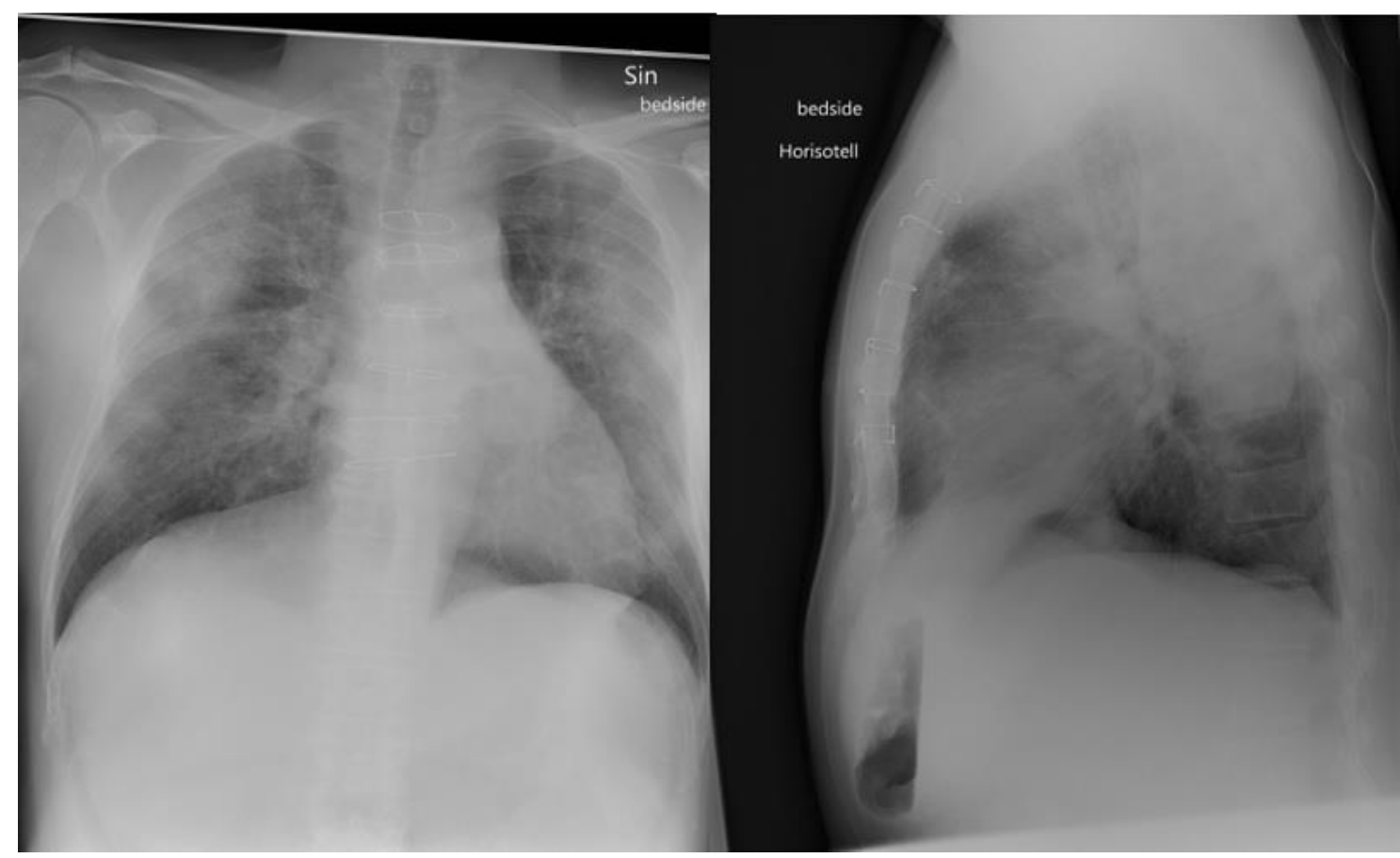

Fonte: Ahre, A. M. (2020). COVID-19 pneumonia. Disponível em: https://radiopaedia.org/cases/covid-19-pneumonia-15?lang=us.

Figura 4: Paciente feminino, 50 anos, positivo por COVID-19, com tosse produtiva e faringite por 01 semana. Radiografia: Várias pequenas áreas bilaterais de opacificação confluente irregular, incluindo uma opacidade arredondada (círculo) discreta na zona inferior direita.

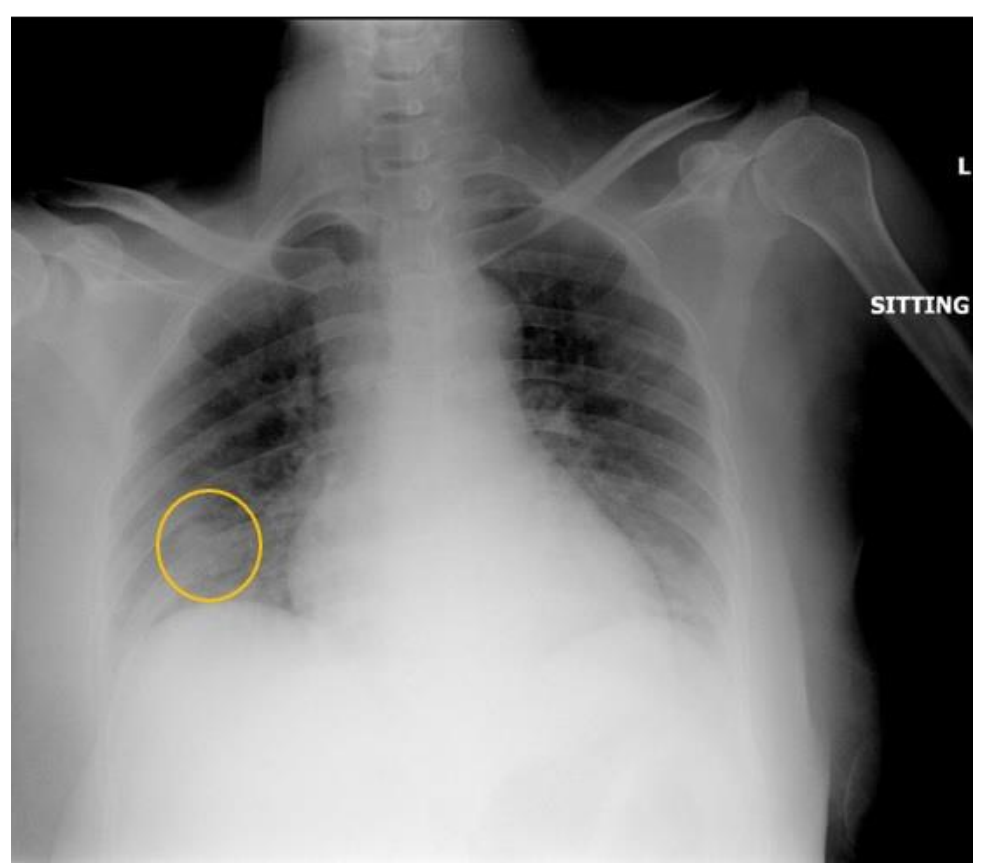

Fonte: Sam, C. K. S. (2020). COVID-19

pneumonia. Disponível em: https://radiopaedia.org/cases /covid-19-pneumonia-2. 
Figura 5: Paciente masculino, 83 anos, com insuficiência mitral, hipertensão pulmonar e fibrilação atrial com infecção por COVID-19. Radiografia: Opacificação em vidro fosco e consolidação no lobo superior direito e lobo inferior esquerdo (setas).

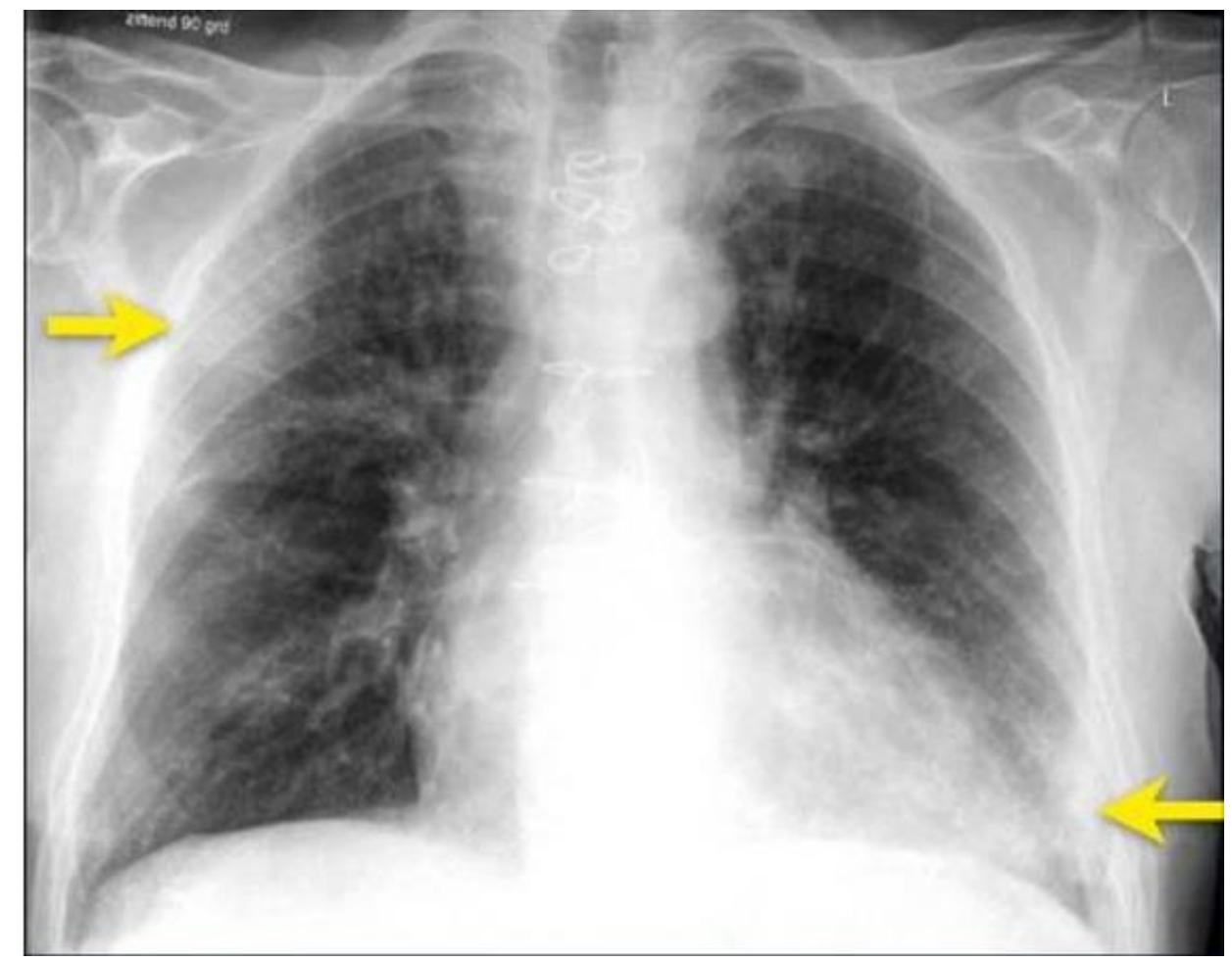

Fonte: Smithuis, R. (2020).COVID-19: imaging findings. Disponível em: https://radiologyassistant.nl/chest/lk-jg-1.

\section{Tomografia Computadorizada de Alta Resolução (TCAR) de Tórax}

A TC não deve ser utilizada como rastreio ou diagnóstico (Colégio Brasileiro de Radiologia, 2020). Seu uso deve ser reservado para pacientes sintomáticos hospitalizados ou situações clínicas específicas, pois achados da TC não alteram desfechos. Quando indicada, o protocolo é de uma TCAR com protocolo de baixa dose, se possível. O uso de meio de contraste endovenoso é reservado para situações específicas a serem determinadas pelo radiologista (Colégio Brasileiro de Radiologia, 2020; World Health Organization, 2020a). Os achados da TCAR são (Colégio Brasileiro de Radiologia, 2020; F. Pan et al., 2020; Y. Pan et al., 2020).

\section{Fase inicial (0-2 dias do início dos sintomas):}

- TC sem anormalidades (50\%);

- Opacidade de atenuação em vidro fosco (o mais comum) focais ou multifocais; 
- Consolidação;

- Lesões de distribuição bilateral e periférica.

Fase intermediária (5-8 dias):

- TC pode ser normal $(<10 \%)$;

- Apresenta progressão das lesões;

- Acometimento bilateral e periférico na maioria das vezes.

\section{Fase tardia (9-12 dias):}

- TC pode ser normal $(<5 \%)$;

- Consolidação $(60 \%)$;

- Padrão de pavimentação em mosaico (linhas interlobulares e intralobulares espessas em combinação com um padrão de vidro fosco);

- Opacidades reticulares.

São descritos 04 (quatro) padrões tomográficos de laudo/classificação da COVID-19, são eles (American College of Radiology, 2020):

- TÍPICOS: Áreas em vidro fosco/consolidativas e pavimentação em mosaico periféricas e multifocais bilaterais;

- INDETERMINADOS: Opacidades em vidro fosco sem distribuição periféricas;

- ATÍPICOS: Padrões pulmonares diversos, sem vidro fosco e/ou consolidações (exemplos: escavações, padrão de "árvora em brotamento");

- NEGATIVO: Tomografia computadorizada normal.

O desaparecimento das lesões é lento, com duração, em média, de 01 (um) mês (F. Pan et al., 2020; Y. Pan et al., 2020)

Não é comum a presença de derrame pleural, linfonodomegalia, cavitações, pneumotórax, padrão nódulo centrolobular/"árvore em brotamento" e padrão de pneumonia lobar (Figura 14). Nestes casos, considera-se a possibilidade de diagnósticos diferenciais (Perlman, 2020; Rodrigues et al., 2020).

Como já citado, exames de imagem não servem para diagnóstico ou exclusão de COVID-19, pois os achados são inespecíficos. Assim, há a necessidade de se realizar diagnósticos diferenciais, os principais são: pneumonias virais (influenza, citomegalovírus- 
CMV), pneumonia bacteriana atípica (micoplasma, clamídia), pneumocistose e pneumonia em organização critogênica (Dai et al., 2020; Li et al., 2020; Simpson et al., 2020).

Figura 6: Homem, 52 anos com RT-PCR positivo para COVID-19. TC na janela pulmonar e corte axial apresenta opacidade em atenuação de vidro fosco bilateral, multifocal (asteriscos) e periférico (setas) com espessamento septal interlobular sobreposto e linhas intralobulares visíveis (Pavimentação em mosaico).

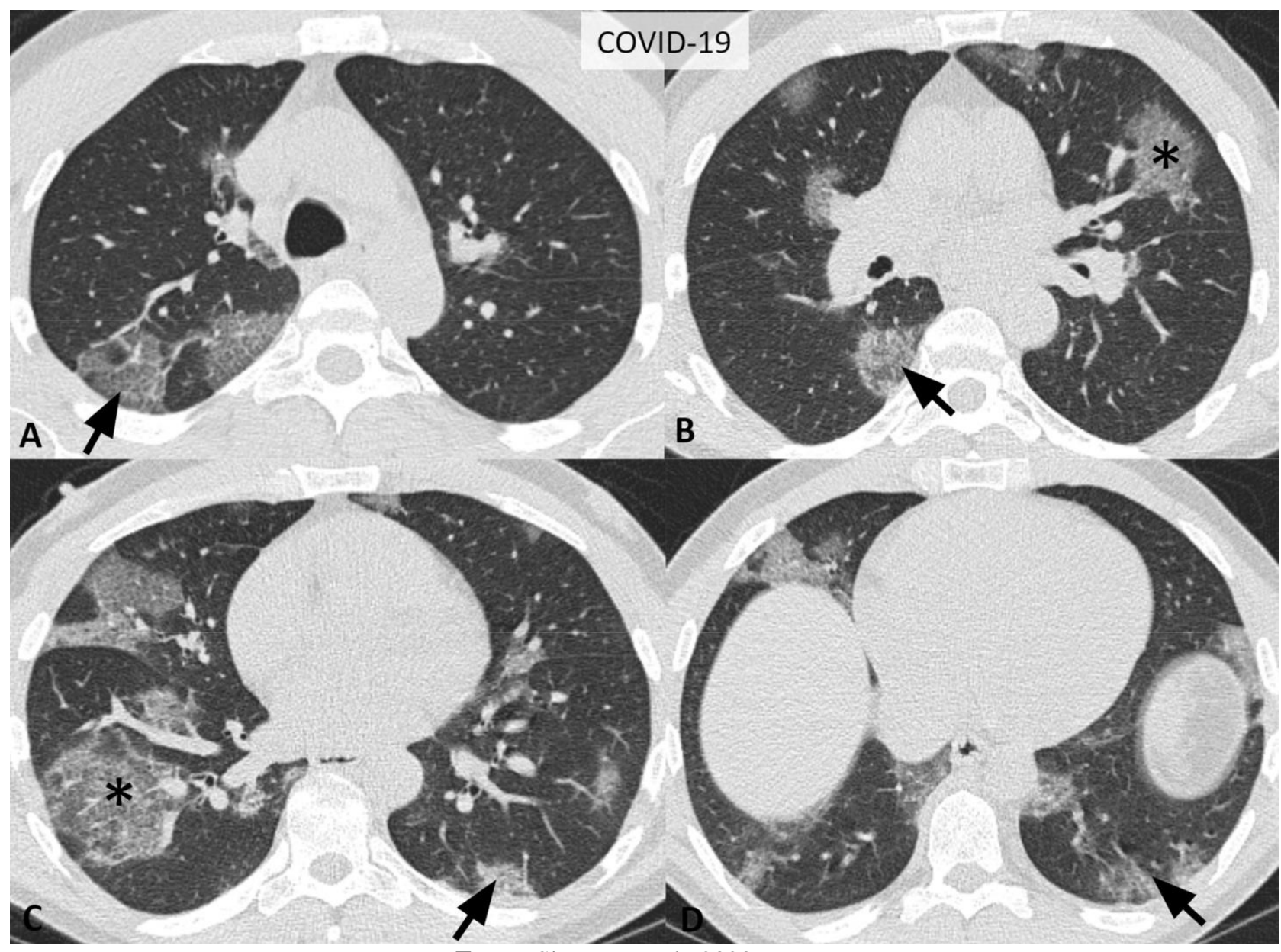

Fonte: Simpson et al., 2020 
Figura 7: Paciente feminino, 35 anos, com febre, tosse, dispneia há 3 dias, saturação 70\%, RT-PCR positivo para COVID-19. TC na janela pulmonar e corte axial apresenta opacidades em vidro fosco confluentes bilaterais pronunciadas principalmente na periferia dos pulmões (setas).

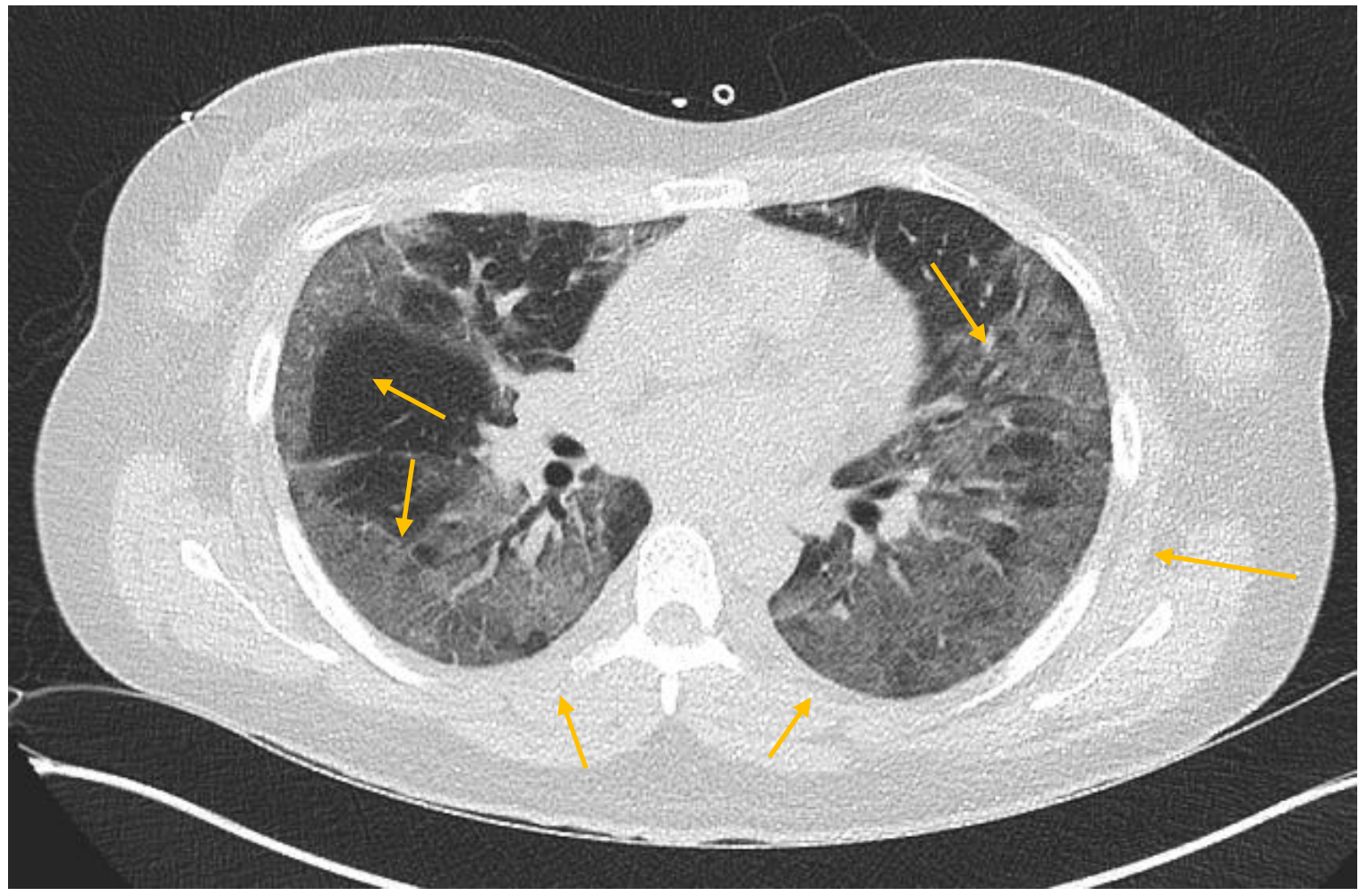

Fonte: Vandermeulen, H. (2020). COVID-19 pneumonia. Disponível em: https://radiopaedia.org/cases/covid-19pneumonia-40?lang=us.

Figura 8: Homem, 77 anos com RT-PCR positivo para COVID-19. TC na janela pulmonar em cortes axial (A, B e C) e coronal (D) apresenta opacidades em vidro fosco bilateral, multifocal e periféricas (setas).

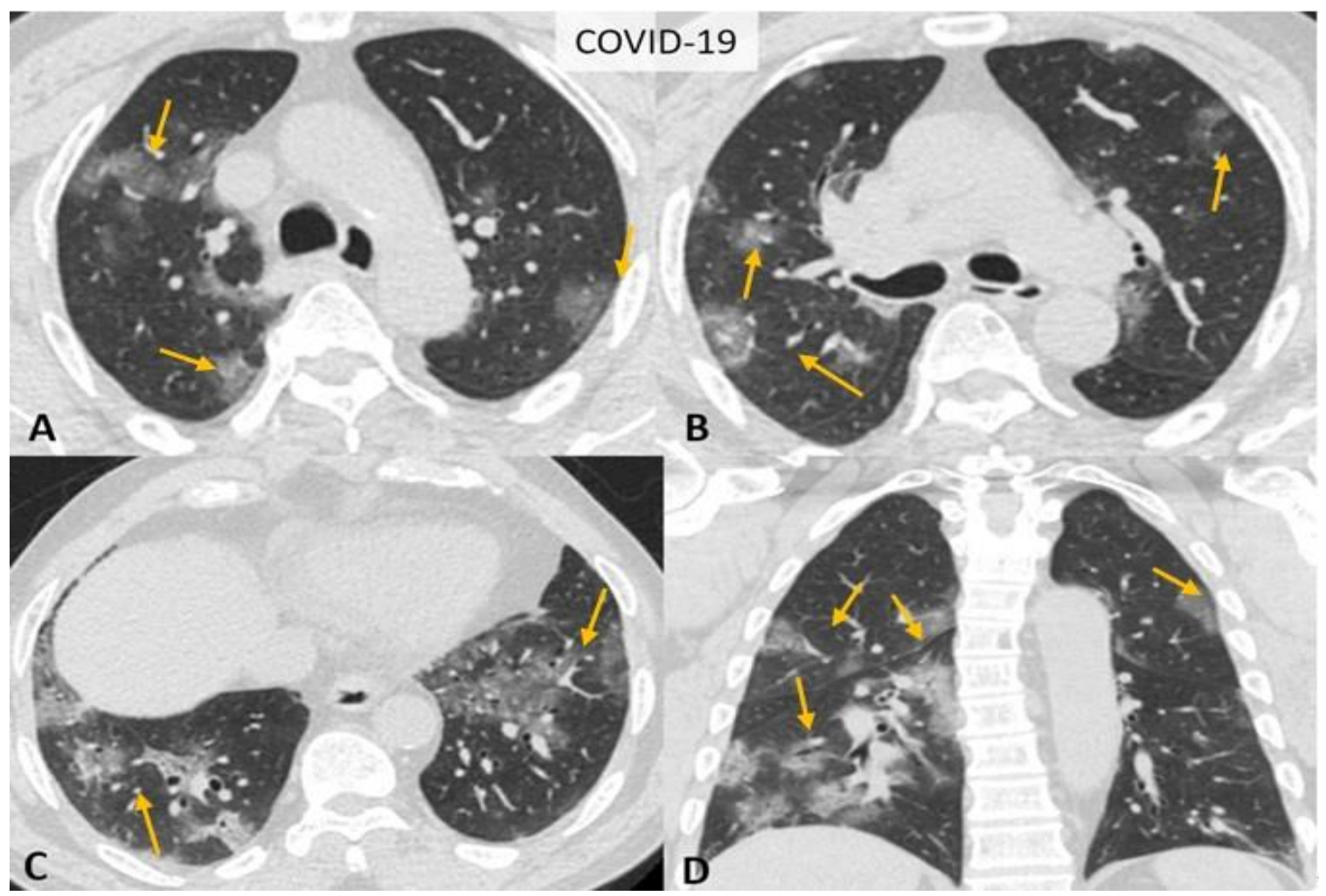

Fonte: Simpson et al., 2020. 
Figura 9: Acompanhamento da TC de tórax em um paciente que teve contato com um paciente com infecção confirmada por COVID-19. Os cortes axiais do dia 0 da admissão no hospital mostram opacidades em vidro fosco no lobo inferior esquerdo (imagem A, seta), mas não no lobo superior direito (imagem C). Posteriormente, no $3^{\circ}$ dia, a TC de acompanhamento mostrou aumento das alterações no vidro fosco com alguma consolidação periférica (sinal do halo invertido, imagem B, seta) e novas opacidades de vidro fosco na periferia do lobo superior direito (imagem D, seta).

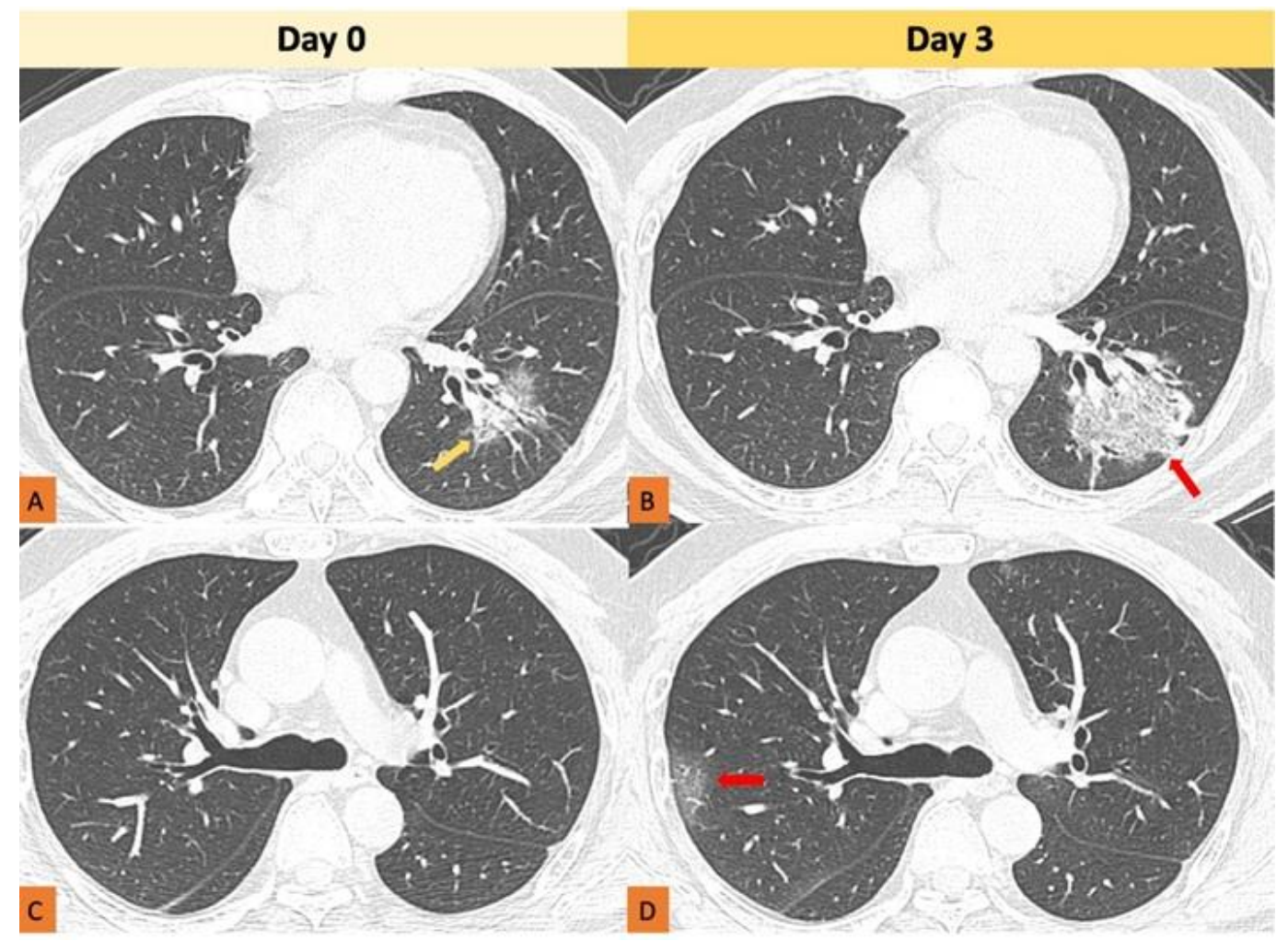

Fonte: $\mathrm{Ng}$ et al., 2020.

Figura 10: Idoso, 85 anos, diabético e dpocítico, apresentando dispneia. TC realizada no $3^{\circ}$ dia da admissão, após agravamento do quadro, apresentando consolidações subpleurais (setas) com opacidades em vidro fosco periféricas. A RT-PCR positivou para COVID-19.

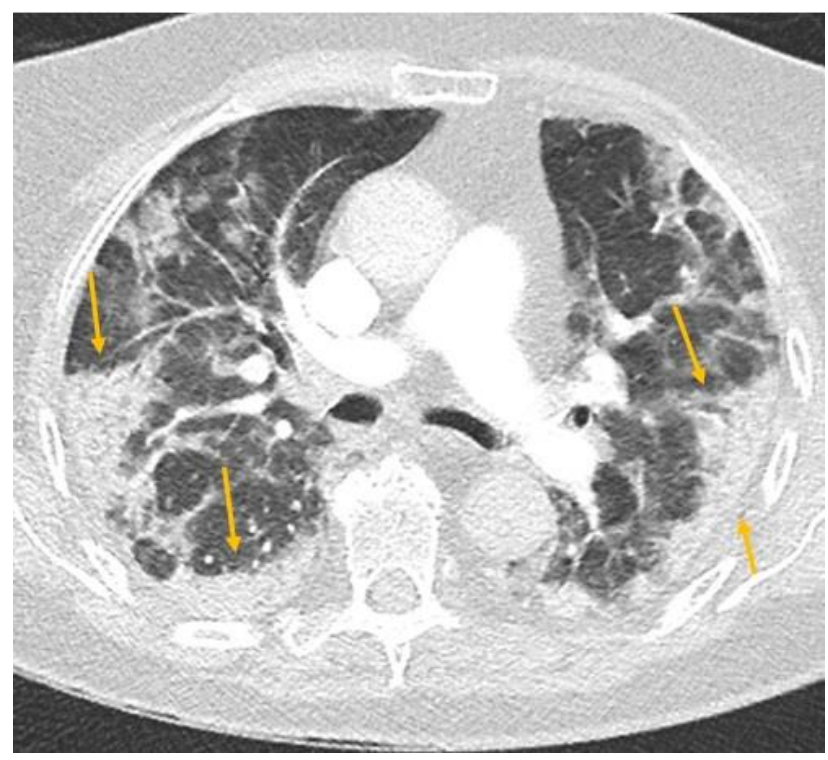

Fonte: Patel, R. (2020). COVID-19 pneumonia. Disponível em: https://radiopaedia.org/cases/covid-19pneumonia-42?lang=us. 
Figura 11: Homem, 29 anos, com RT-PCR positivo. TC na janela pulmonar, em cortes axias (A, B e C) e sagital (D), apresenta múltiplas consolidações bilaterais e arredondadas com opacidade em vidro fosco circundante (círculos).

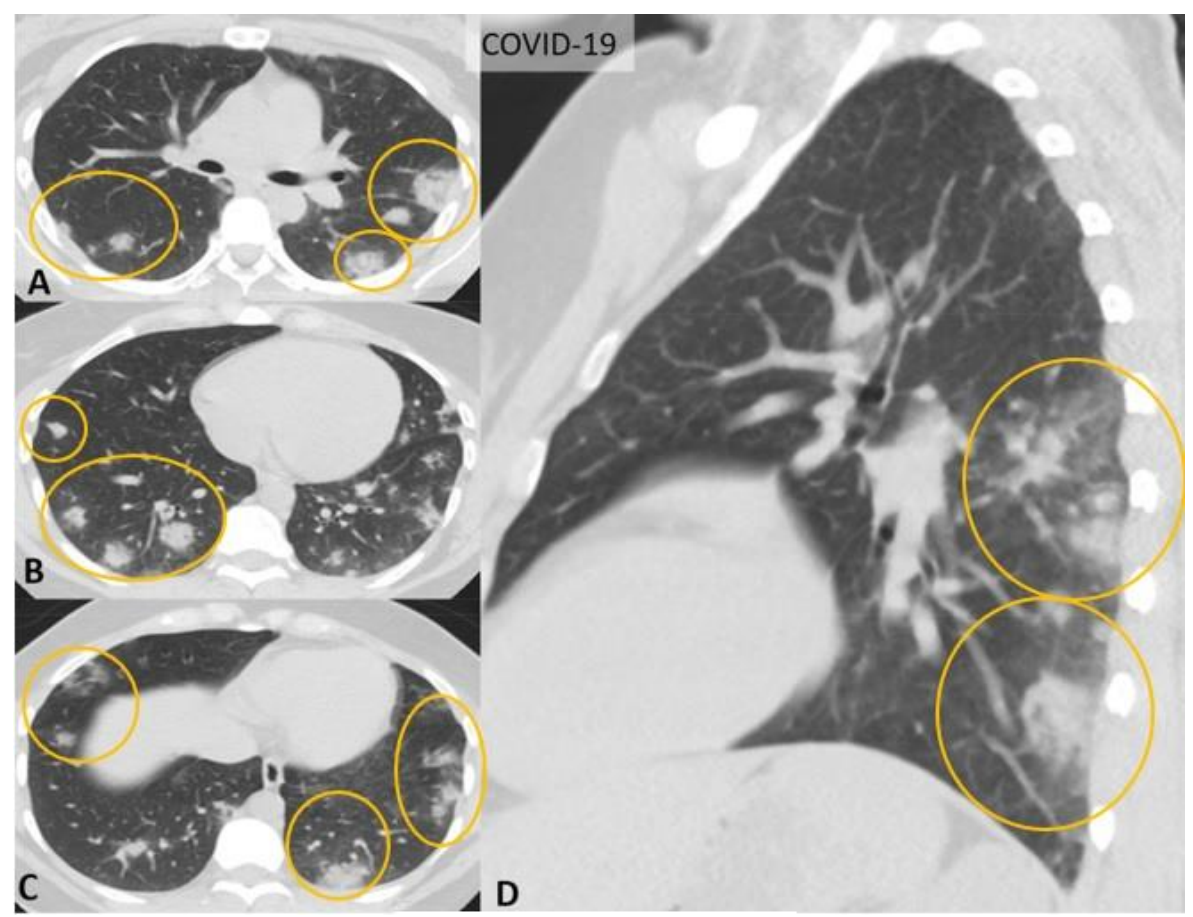

Fonte: Simpson et al., 2020.

Figura 12: Mulher, 59 anos, história de 10 dias de febre e 05 dias de tosse, saturação $89 \%$ e frequência respiratória de $30 \mathrm{irpm}$. TC na janela pulmonar, corte axial, apresenta opacidades de atenuação em vidro fosco difusos bilateralmente. O RT-PCR positivou para COVID-19.

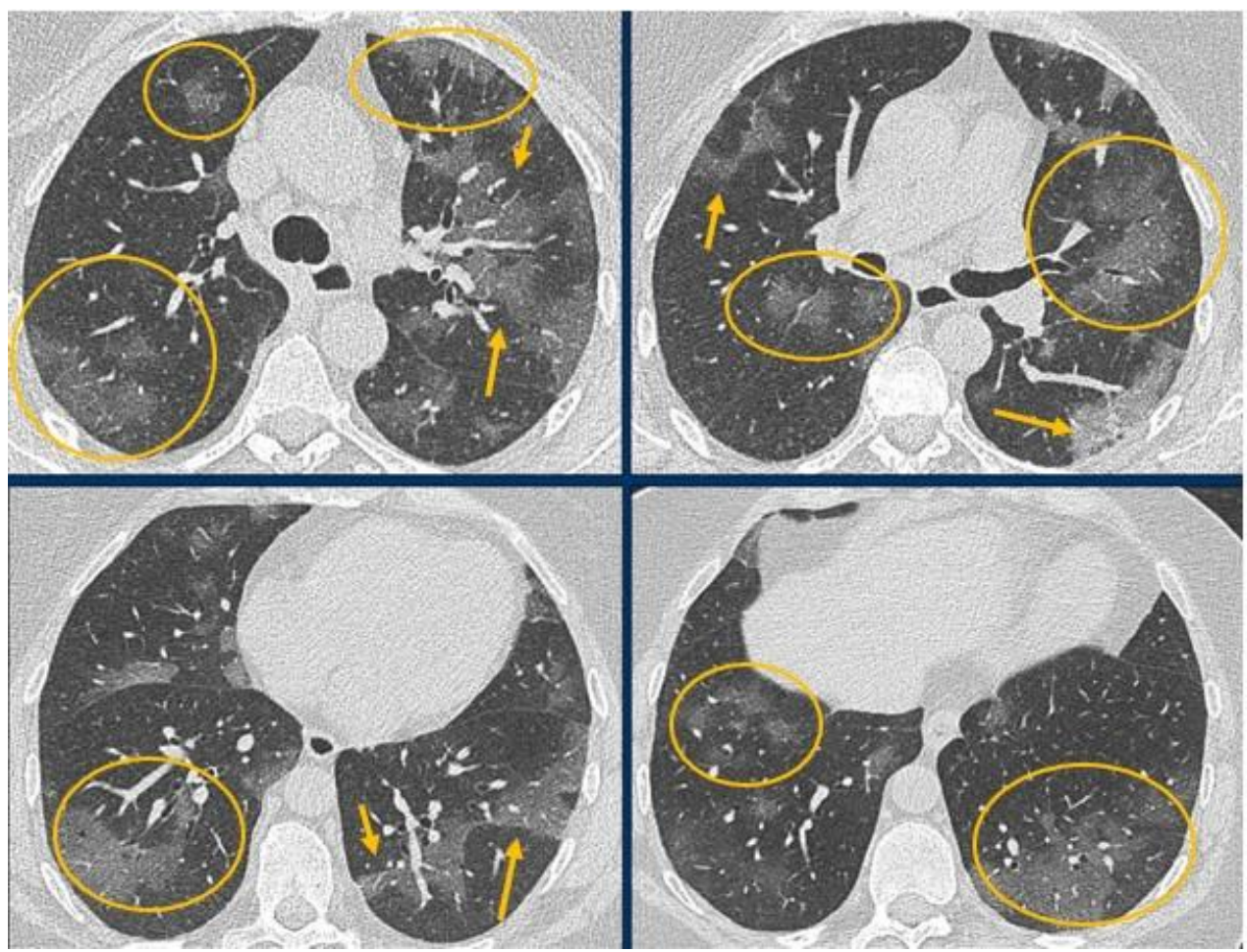

Fonte: Smithuis, R. COVID-19: imaging findings. Disponível em: https://radiologyassistant.nl/chest/lk-jg-1. 
Figura 13: Homem, 59 anos, apresentando febre e tosse seca por 07 dias. Inicialmente, o RT-PCR para COVID-19 foi negativo. Por suspeita clínica, uma realizada um TC que apresentou áreas de opacificação em vidro fosco (setas roxas) e consolidação em segmento posterior dos lobos inferiores (setas amarelas). 02 dias depois da TC, o RT-PCR foi positivo.

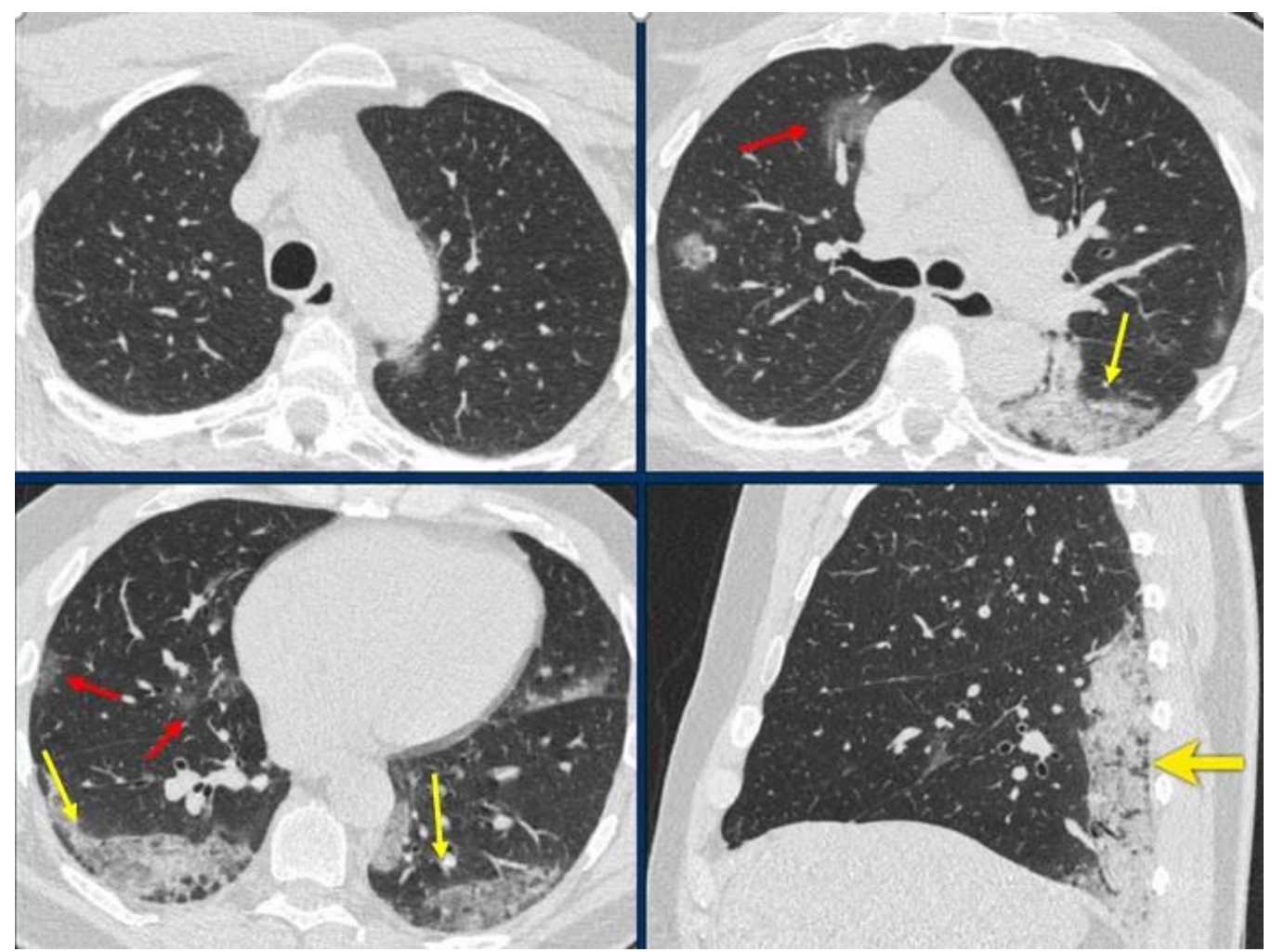

Fonte: Smithuis, R. (2020). COVID-19: imaging findings. Disponível em: https://radiologyassistant.nl/chest/lk-jg-1.

Figura 14: Paciente positivo pra COVID-19. TC de janela pulmonar com contraste (A) e Rx de tórax em AP (B) apresentam consolidação segmentar sem opacidade de atenuação em vidro fosco significativo. Embora esse paciente tenha testado posivito para SARS-CoV-2, os achados de imagem não são típicos e podem representar pneumonia relacionado ao COVID-19 ou a um processo infecciosa secundário.

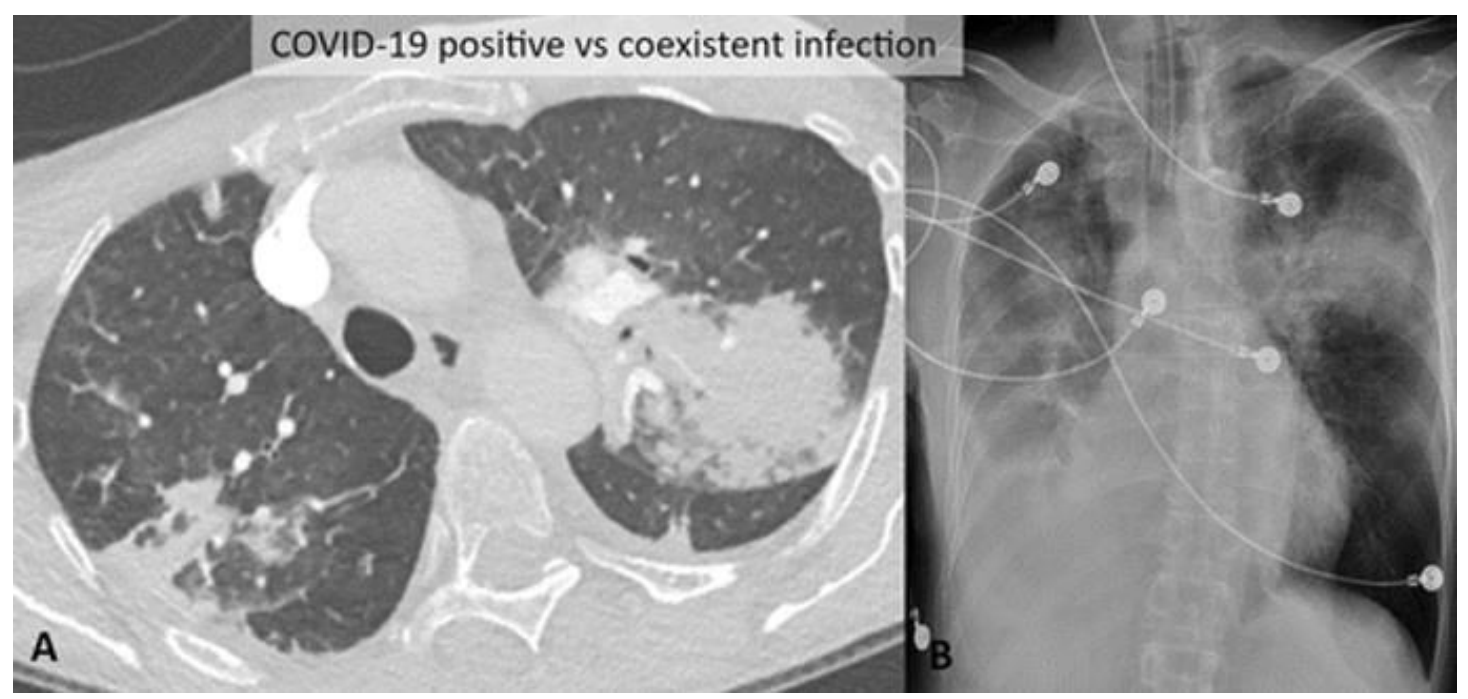

Fonte: Simpson et al., 2020 . 
Figura 15: Achados típicos de COVID-19 na TC e outras doenças com achados semelhantes. Opacidade em vidro fosco posterior, periférico e consolidação em imagens axiais de 4 pacientes: A e B: COVID-19; C: Pneumonia em organização secundária a dermatomiosite. D: Pneumonia por influenza A. Os achados de pneumonia em organização e pneumonia por influenza podem ser indistinguíveis do COVID-19 pela TC.

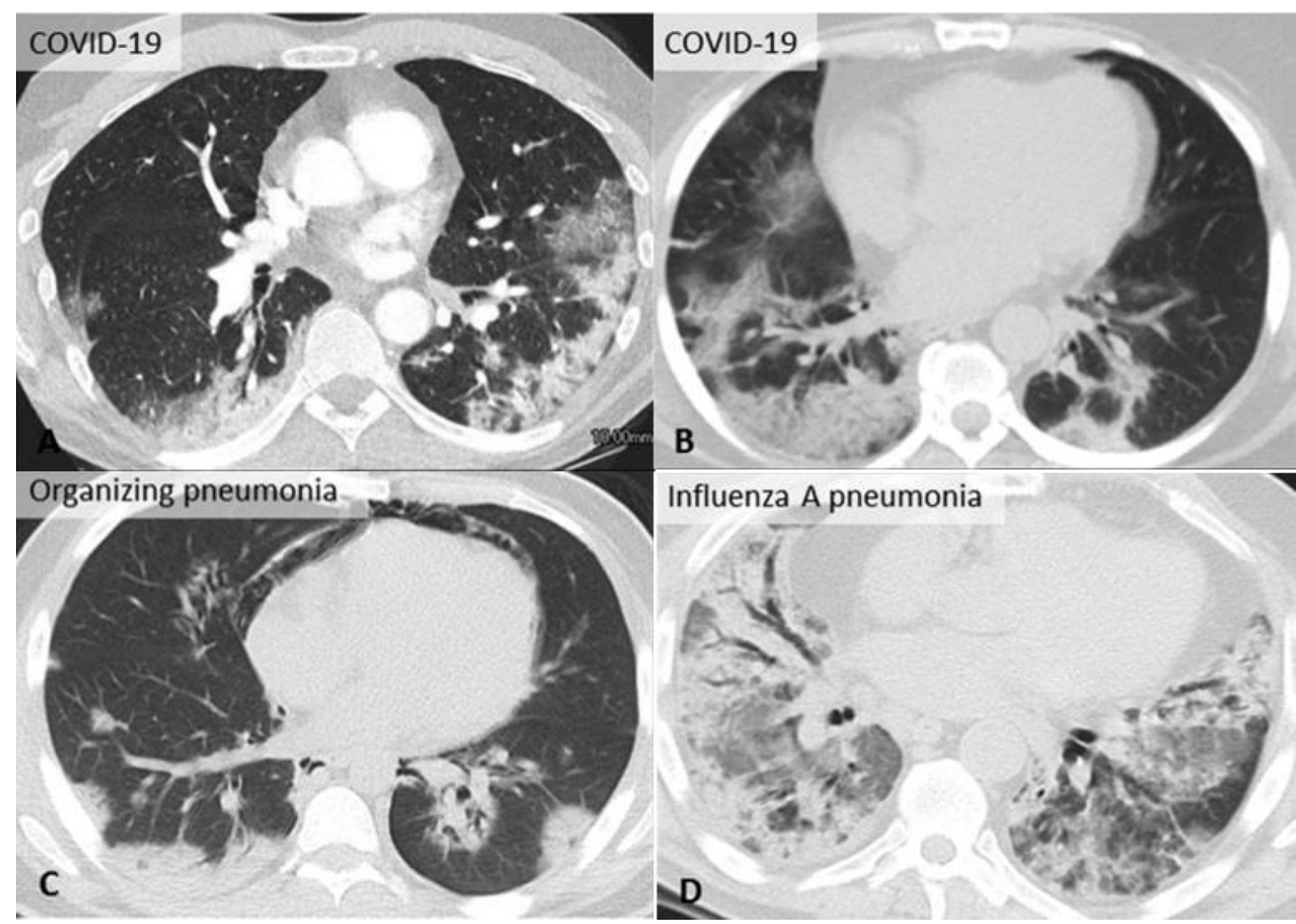

Fonte: Simpson et al., 2020.

\section{Conclusões}

A partir da definição de casos suspeito pela apresentação de sintomas de via aérea superior, a confirmação diagnóstica se dá pela presença de partículas virais presentes no organismo do indivíduo infectado pela RT-PCR.

Os exames de imagem contribuem na investigação da suspeita de infecção pelo coronavírus e exclusão de outras patologias respiratórias que iram se manifestar com diferentes padrões radiológicos.

A tomografia computadorizada de tórax é de fácil execução e boa disponibilidade, atua como adjuvante para a detecção precoce de lesões pulmonares características da pneumonia viral pelo coronavírus (COVID-19), auxilia na distinção de possíveis diagnósticos diferenciais e avaliação de gravidade dos pacientes hospitalizados. 
Para efeito de triagem, a TC não deve ser usada nos casos de suspeita de COVID-19 em pacientes assintomáticos. A mesma deverá ser considerada para os casos de pacientes hospitalizados, com sintomas ou naquelas situações clínicas específicas.

Os achados radiológicos nos casos de pneumonia por COVID-19 nem sempre são inespecíficos, pois assemelha-se aos de outras infecções pulmonares. Apresentam variações de acordo com a fase da doença, portanto, devem ser correlacionados com outras evidências clínicas e laboratoriais referentes a infecção por COVID-19.

Até o presente momento, o que tem sido recomendado é que o diagnóstico final da doença seja primeiro confirmado por teste positivo de RT-PCR ou por testes de sequenciamento genético. O profissional Clínicos ou radiologista necessita estar familiarizado com a situação do acometimento do COVID-19, estando aptos e alertas para identificação e tratamento do paciente acometido, o mais precocemente possível, mesmo que sejam poucos os sintomas clínicos evidentes, achados de tomografias de tórax normais e até mesmo com testes laboratoriais iniciais negativos.

\section{Referências}

Ahre, A. M. (2020). COVID-19 pneumonia. Disponível em: https://radiopaedia. org/cases/covid19-pneumonia-15?lang=us.

American College of Radiology. (2020). ACR COVID-19 Clinical Resources for Radiologists. Disponível em: https://www.acr.org/Clinical-Resources/COVID-19-Radiology-Resources

Centers For Disease Control And Prevention. (2020a). How covid spreads. Disponível em: https://www.cdc.gov/coronavirus/2019-ncov/prevent-gettingsick/prevention.html?CDC_AA_refVal=https $\% 3 \mathrm{~A} \% 2 \mathrm{~F} \% 2 \mathrm{Fwww} . c d c . g o v \% 2 \mathrm{Fcoronavirus} \% 2 \mathrm{~F} 2$ 019-ncov\%2Fprepare\%2Fprevention.html.

Centers For Disease Control And Prevention. (2020b). How to Protect Yourself \& Others. Disponível em: https://www.cdc.gov/coronavirus/2019-ncov/prevent-gettingsick/prevention.html?CDC_AA_refVal=https $\% 3 \mathrm{~A} \% 2 \mathrm{~F} \% 2 \mathrm{Fwww} . c d c . g o v \% 2 \mathrm{Fcoronavirus} \% 2 \mathrm{~F} 2$ 019-ncov\%2Fprepare\%2Fprevention.html.

Centers For Disease Control And Prevention. (2020c). People who are at higher risk for severe illness. Disponível em: https://www.cdc.gov/coronavirus/2019-ncov/need-extraprecautions/people-at-higher-risk.html.

Centers For Disease Control And Prevention. (2020d). What to Do If You Are Sick. Disponível em: https://www.cdc.gov/coronavirus/2019-ncov/if-you-are-sick/steps-when-sick.html?CDC_ AA_refVal=https $\% 3 \mathrm{~A} \% 2 \mathrm{~F} \% 2 \mathrm{Fwww} . c d c . g o v \% 2 \mathrm{Fcoronavirus} \% 2 \mathrm{~F} 2019-\mathrm{ncov} \% 2 \mathrm{Fabout} \% 2$ Fsteps-when-sick.html. 
Chen, Y., Liu, Q., \& Guo, D. (2020). Emerging coronaviruses: Genome structure, replication, and pathogenesis. Journal of Medical Virology, 92 (4), 418-423.

Colégio Brasileiro de Radiologia. (2020). Recomendações de uso de métodos de imagem para pacientes suspeitos de infecção pelo COVID-19. Disponível em: https://cbr.org.br/wpcontent/uploads/2020/03/CBR_Recomenda\%C3\%A7\%C3\%B5es-de-uso-de-m\%C3\%A9todosde-imagem_16-03-2020.pdf.

Dai, W. et al. (2020). CT Imaging and Differential Diagnosis of COVID-19. Canadian Association Of Radiologists Journal, 1-6.

Guan, W. et al. (2020). Clinical Characteristics of Coronavirus Disease 2019 in China. New England Journal Of Medicine, 1-13.

Heymann, D. L. \& Shindo, N. (2020). COVID-19: what is next for public health?. The Lancet, 395 (10224), 542-545.

Hui, D. S. et al. (2020). The continuing 2019-nCoV epidemic threat of novel coronaviruses to global health - The latest 2019 novel coronavirus outbreak in Wuhan, China. International Journal Of Infectious Diseases, 91, 264-266.

Kanne, J. P. et al. (2020). Essentials for Radiologists on COVID-19: An Update-Radiology Scientific Expert Panel. Radiology, 1-4.

Lauer, S. A. et al. (2020). The Incubation Period of Coronavirus Disease 2019 (COVID-19) From Publicly Reported Confirmed Cases: Estimation and Application. Annals Of Internal Medicine.

Li, Y. et al. (2020). Coronavirus Disease 2019 (COVID-19): Role of Chest CT in Diagnosis and Management. American Journal Of Roentgenology, 1-7.

Lorente, E. (2020). COVID-19 pneumonia. Disponível em: https://radiopaedia.org/cases/covid19-pneumonia-21?lang=us.

Mossa-Basha, M. et al. (2020). Radiology Department Preparedness for COVID-19: radiology scientific expert panel. Radiology Scientific Expert Panel. Radiology, 1-15.

Ng, L. F. P. \& Hiscox, J. A. (2020). Coronaviruses in animals and humans. BMJ, 1-2.

$\mathrm{Ng}$, M. et al. (2020). Imaging Profile of the COVID-19 Infection: Radiologic Findings and Literature Review. Radiology: Cardiothoracic Imaging, 2 (1), 1-26.

Pan, F. et al. (2020). Time Course of Lung Changes On Chest CT During Recovery From 2019 Novel Coronavirus (COVID-19) Pneumonia. Radiology, 1-15.

Pan, Y. et al. (2020). Initial CT findings and temporal changes in patients with the novel coronavirus pneumonia (2019-nCoV): a study of 63 patients in Wuhan, China. European Radiology, 1-6.

Patel, R. (2020). COVID-19 pneumonia. Disponível em: https://radiopaedia.org/cases/covid-19pneumonia-42?lang=us. 
Perlman, S. (2020). Another Decade, Another Coronavirus. New England Journal Of Medicine, $382(8), 760-762$.

Rodrigues, J.C.L. et al. (2020). An update on COVID-19 for the radiologist - A British society of Thoracic Imaging statement. Clinical Radiology, 1-3.

Sam, C. K. S. (2020). COVID-19 pneumonia. Disponível em: https://radiopaedia.org /cases/covid-19-pneumonia-2.

Simpson, S. et al. (2020). Radiological Society of North America Expert Consensus Statement on Reporting Chest CT Findings Related to COVID-19. Endorsed by the Society of Thoracic Radiology, the American College of Radiology, and RSNA. Radiology: Cardiothoracic Imaging, 2 (2), 1-24.

Smithuis, R. (2020). COVID-19: imaging findings. Disponível em: https://radiologyassistant. nl/chest/lk-jg-1.

Vandermeulen, H. (2020). COVID-19 pneumonia. Disponível em: https://radiopaedia.org/cases/covid-19-pneumonia-40?lang=us.

World Health Organization. (2020a). Clinical management of severe acute respiratory infection (SARI) when COVID-19 disease is suspected. Disponível em: https://www.who.int/ docs/default-source/coronaviruse/clinical-management-of-novel-cov.pdf.

World Health Organization. (2020b). Report of the WHO-China Joint Mission on Coronavirus Disease 2019 (COVID-19). Disponível em: https://www.who.int/publications-detail/report-ofthe-who-china-joint-mission-on-coronavirus-disease-2019-(covid-19).

$\mathrm{Xu}, \mathrm{H}$. et al. (2020). High expression of ACE2 receptor of 2019-nCoV on the epithelial cells of oral mucosa. International Journal Of Oral Science, 12 (1), 1-5.

Zhang, H. et al. (2020). Angiotensin-converting enzyme 2 (ACE2) as a SARS-CoV-2 receptor: molecular mechanisms and potential therapeutic target. Intensive Care Medicine, 46 (4), 586590.

Zheng, Y. et al. (2020). COVID-19 and the cardiovascular system. Nature Reviews Cardiology, $1-2$.

\section{How to cite this article (APA format):}

Albuquerque, Lucas Tavares Cruz de; Modesto, Caroline Pereira; Albuquerque, Ana Beatriz Tavares Cruz de; Vasconcelos, Danilo Campos de Moraes; Pinheiro, Raphael Xenofonte Morais (2020). Radiological Images In Covid-19: An Integrative Review. Am. In. Mult. J., February to May. (8) 5, 79-97.

Received: 05/07/2020;

Accepted: 05/14/2020. 